\title{
IMPORTANCE OF A DIALOGUE BETWEEN LOCAL GOVERNMENT AND BUSINESS FOR URBAN DEVELOPMENT
}

\author{
Tomasz Ankiewicz, Zofia Wyszkowska ${ }^{\mathrm{b}}$, Tomasz Michalski ${ }^{\mathrm{c}}$ \\ a,b,c University of Science and Technology, Bydgoszcz, Poland \\ ae-mail: t.ankiewicz@wp.pl \\ be-mail: zofiawyszkowska@zomed.pl \\ ce-mail: atm3@poczta.onet.pl
}

\begin{abstract}
Aim: The following article determines the importance of the dialogue between the municipal government and local business. It also describes its influence on the city's development and its inhabitants' lives. The authors have verified the hypothesis that the dialogue between the municipal government and local business brings multilateral advantages for the former and the later as well as for the local community. It also creates a positive image of the town where well sustained cooperation becomes extremely helpful in creating long-term town strategy.
\end{abstract}

Methodology: The research has mainly been based on the literature analysis concerning intersegmental cooperation and economic development as well as a case study. The case study concerns the municipal district of Lubawa which is considered to be one of the most dynamically developing towns in Warmian-Masurian Voivodeship. The data has been obtained from the City Council of Lubawa and covers the range between 2007 and 2017.

Genuity/quality: The article is of great value for people responsible for creating a positive image of the city and establishing its development strategy based on accessible resources as well as for enterpreneurs interested in investing in small municipalities.

Keywords: local government, municipality, local authorities, economic development

Paper type: Research paper

\section{Introduction}

The desired characteristics of modern regional development are integrity, innovativeness and sustainability. Economic development should be shaped by the effects and the use of both internal and external factors, paying particular attention to diffusion of innovations (Zakrzewska-Póttorak, 2010). An important role in this process is played by local authorities, whose policy should be a sustainable, planned process of initiating changes in business surroundings to enable entrepreneurs to understand the actions of local administration bodies in the long term and to use them as part of their own development activity. Strategic 
IMPORTANCE OF A DIALOGUE BETWEEN

Tomasz Ankiewicz Zofia Wyszkowska Tomasz Michalski planning, implementation of policies and development of entrepreneurship on the local level are an important step to define the identity of a given place and to stimulate changes in the economic sphere (Cieślik and Koładkiewicz, 2014). While stimulating local economic development, local authorities have a wide range of tools at their disposal to achieve established targets. The choice of the right set of instruments depends on their speed, expected results and ease of use of such instruments. Therefore, such tools may be varied (Kamiński, 2003).

\section{Aim of the paper and research methodology}

The main aim of the article is to analyse the role and importance of a dialogue between local government and business in terms of economic development of the municipality and improvement of the quality of life of its residents.

The article presents a case study of the municipality of Lubawa, which for many years has been considered one of the most dynamically developing cities in Warmia-Masuria Province. The research method was analysis of documents and materials obtained from the Lubawa Town Council for 2007-2017. Research material was also obtained through an in-depth interview with a member of staff from the Lubawa Town Council responsible for investments carried out on behalf of the Town Council. The study was conducted between January and February 2018.

\section{The role of local authorities in the development of entrepreneurship in the region}

Cooperation of various entities being present in regional and local reality determines strong and sustainable social and economic development of regions, cities and communes. This local development's factor is mentioned by numerous scholars and practitioners, including Dziemianowicz (2008), Piasecki (2009), Kuciński (2010), Bański (2015). Recently, significant cooperation of public, commercial and social sector is expected. Its outcome is the formation of the coalition, network and different types of agreements altering current administrative and economic structures. What makes the partnership successful is its long-lasting effects, and not satisfactory, peaceful closure (Baron, 2005). Contemporary development strategies reveal the evolution that occurs within the area of regional development policy. It is shifting from authoritatively distributed and short-term grants for the least developed regions to long-term and decentralised development policies targeted at supporting all regions and more selective investments. It requires higher activity and commitment of local and regional authorities in forming and implementing development policy (Mazur, 2015).

Local government units play an important role in stimulating and controlling development processes on strictly defined territories, which constitute the area of activity for many economic and social entities. Such entities follow different 
objectives and criteria while choosing the location of their activity. However, it is necessary for such entities to coordinate their actions and to follow directions that are aligned with social expectations and internal circumstances. A particularly important role is played by municipalities, which become the link between local business and the society (Filipiak and Ruszała, 2009).

Every municipality has a specific economic potential, human capital and a more or less well identified group of entrepreneurs at its disposal, which can activate the existing potential. It is the job of municipalities to create conditions favourable to taking action. By creating conditions favourable to the development of entrepreneurship, local authorities can enjoy tangible results in the form of an increased employment rate, more investments in the municipality, a growth of revenues generated by the municipality and more affluent residents (Kłodziński, 2006). Regional economic development requires not only strong businesses but also cooperation with other entities in order to create a stable basis for development. Source literature highlights the importance of cooperation between different entities, as only such cooperation between different entities working for the same goal, i.e. development, can create synergy. Therefore, the surroundings in which companies operate have an important influence on the development of entrepreneurship. An important role is played by business support institutions, which are non-profit organisations operating not for profit or using any profit for purposes provided for in their statute or an equivalent document, which take actions to support the development of entrepreneurship, innovation and socioeconomic development (Filipiak and Ruszała, 2009). Business support institutions are responsible for, in particular (Filipiak and Ruszała, 2009):

- creating favourable conditions with regard to the transfer of new technological solutions (technology transfer centres - TTC, technology incubators),

- raising the quality of human resources in business by providing training and counselling (training and counselling centres),

- supporting cooperative links between companies,

- building a network of cooperation (among others clusters) and animating the innovative business environment (science and technology parks),

- financing innovation (seed capital, venture capital, business angels) and development,

- protecting intellectual property rights,

- supporting self-employment,

- supporting start-ups and helping newly established enterprises,

- marketing and promotion.

Cooperation between local government and business support institutions can contribute positively to developing an understanding of the needs of entrepreneurs, elimination of barriers obstructing their development and to understanding the

IMPORTANCE OF

A DIALOGUE BETWEEN

Tomasz Ankiewicz Zofia Wyszkowska

Tomasz Michalski 
IMPORTANCE OF A DIALOGUE BETWEEN

Tomasz Ankiewicz Zofia Wyszkowska Tomasz Michalski principles of local government's operation and statutory limitations with regard to the scope of support granted.

The image of local entrepreneurship is shaped by the attitudes and behaviours of public authorities, business entities and the local community - which are correlated and affect each other - aimed at seeking new uses for the resources held and for new opportunities for growing such resources, identifying and creating new needs, predicting future directions of development of needs and production technologies and adjusting the economic potential accordingly (Janik, 2004). Local authorities should maintain permanent, close relations with companies operating on their territory to be able to prevent any emerging difficulties in time. This is not an easy task, as businesses are unwilling to share their problems with local authorities. In general, local authorities show poor awareness of the economic position of businesses and their contact with local businesses is often limited to applications for co-financing of various events organised in the municipality (Kłodziński, 2006).

In practice, there is a lack of formalized cooperation between local government and business. In this context it is necessary to form a consistent organization, which for instance could be a self-regulating trade association acting as a mediator as reported by Lunberg and Andersen (Lunberg and Andersen, 2012).

The actions of local government in the investment and organisational sphere are very important for regional and local development. Currently, local public administration bodies use various instruments, procedures and mechanisms for coordination and correction. Investment activities can be carried out both independently by local government units (e.g. budgetary units) or jointly with other economic entities (e.g. commercial companies) or by a number of independent economic entities. Entrepreneurs can rely on different instruments used by local authorities to encourage them and make it easier for them to operate in a given area. While supporting entrepreneurship, local government bodies make direct decisions, for instance on granting reliefs and exemptions from property tax or transportation tax, granting exemptions from fees or lending council property for use (Osiński, 2008). The creation of optimal and competitive conditions for investment's location may occur based on various resources, including: good information, simple and quick procedures, investment climate, territorial marketing (Karaszewski, 2004).

Foreign investments can be the source of many positive changes in the region, as they contribute to the establishment of new workplaces, to initiating technological progress and to stimulating entrepreneurship and cooperation. These effects can be achieved through interaction between the entities participating in the process of choosing a business location, linked to an inflow of direct foreign investments to the given region (Pakulska, 2010). The location factor remains closely linked to capital inflow, contributing to the positive results 
of the investment directly and indirectly. Direct effects can be noticed during negotiations with foreign investors, when local authorities try to negotiate specific outcomes of a given investment. Another example of direct effects is the location of the investment project based on the location of a local company. That is where the first changes take place, which are later reflected in the local economy. Indirect impact is visible once the investment project has been implemented. After the implementation, high qualifications of the work force can revive the labour market as staff with similar qualifications look for work (Dziemianowicz, 2008). Whether a region benefits from enterprises established on the basis of completed foreign investments depends on the level of "embedment" of such enterprises. More "embedment" of an enterprise in the region translates into a higher number of local and regional suppliers of materials and services. With a growing level of embedment of a foreign enterprise, the significance of cooperative links grows. This facilitates the establishment of small and medium enterprises in the local environment. However, there is a risk that the growing position of companies established on the basis of direct foreign investments in the region can be the cause of a fall of family-run companies competing with the foreign enterprise (Pakulska, 2010). This is stressed by Piasecki, who claims that local government should not support all investments. Some of them are disadvantageous to local development. Therefore, for instance, municipal authorities should avoid investing in such types of activity that already exist on the local market and are carried out by other entities. Local government should not support investments that give the municipality a monopoly nor initiatives harmful to the health of local residents or to the environment (Piasecki, 2009). For local government, the increasing number of foreign investors will lead to rising requirement for comprehensive information on the region or commune. Changes connected with increasing significance of information and access to it are beneficial not only for local community members but also for employees of the administration due to the fact that they have positive impact on relations with local and regional economy (Snellen, 2002).

An important factor of municipal economic development is the right promotion of the municipality. The information and promotion sphere is perfect for the application of modern management principles, especially marketing management, at the same time facilitating full use of the latest technologies, mainly ICT. Local administration bodies are by nature the centre of information about the municipality, county or province. They receive information, statistical data, facts and preliminary analyses relating to all aspects of the social, economic and cultural life of the local or regional community (Osiński, 2008). Territorial marketing is based on the idea of social marketing and is linked to a given place or territory as opposed to other forms of marketing, which are mainly industryoriented. It includes different activities related to creating the brand and image

IMPORTANCE OF A DIALOGUE BETWEEN

Tomasz Ankiewicz Zofia Wyszkowska Tomasz Michalski 
IMPORTANCE OF A DIALOGUE BETWEEN

Tomasz Ankiewicz Zofia Wyszkowska Tomasz Michalski of a human settlement. The natural objectives set out in that scope are to create, publicise and maintain a positive image of the municipality. This set of functions can be embedded in a wider range of fiscal activities oriented at acquiring new investors and residents by increasing the attractiveness of the region (Klisiński and Szwaja, 2013). Avraham, by specifying factors influencing the city's image, recognizes its characteristics. He mentions main factors: number of residents and their characteristics, political and socio-economic status of the city, number and nature of national institutions situated within the city, its location and the past, atmosphere as well as tourist and cultural attractions (Avraham, 2004). A strong, positive and distinguishing city's image may attract national and foreign investors together with tourists (Woodside and Lysonski, 1989).

An important role in the municipality management process is played by a document called "Municipal Development Strategy". It is a prospective plan which sets out strategic development objectives, establishes the course of action in the form of operational goals and tasks, and indicates financial means and their sources necessary to implement the established tasks and objectives. To generalise, the strategy contains the rules and methods of managing municipal development in a long term (10-15 years), specifying actions which need to be taken so that the municipality can function and develop. Having such a document is not a statutory obligation for municipalities, which means that despite its usefulness many local authorities do not feel the need to have one (Kłodziński, 2009). A municipal development strategy should be a well-thoughtout vision, containing an objective assessment of the current situation and formulating realistic targets distributed properly in the adopted timeframe. There are concerns about politicising the development strategy, which would make it a purely propagandist document containing a list of targets disproportionate to the resources held and implementation capabilities. Such a misunderstanding of the strategy means that a document prepared in that way is not suitable for future implementation as it does not take into account the capabilities and actual needs of the local community, including entrepreneurs (Cilak, 2013).

If we analyse business support instruments used by local authorities, they can be divided into four groups (Osiński, 2008):

- actions aimed at building and developing a technological infrastructure to help start, maintain and expand business activity,

- promotional and organisational activities aimed at providing entrepreneurs with full information about the conditions of conducting business activity, helping them handle any formalities and promoting enterprises operating within the area governed by the local authorities,

- actions aimed at creating favourable financial conditions for starting and expanding business activity,

- public aid activities, involving direct or indirect provision of financial 
benefits for selected entrepreneurs, giving them an advantage over competitors.

Local government units should not manage the territory by adopting a passive approach to existing and future problems. "Budget to budget" actions should also be avoided. However, Polish experiences indicate that this style of management is quite common, which causes growing conflicts as the actions of local authorities focus on current activity. Emerging new needs of the residents and limited financial resources at the disposal of local authorities require a wellthought-out decision-making process when it comes to how and on what money should be spent. That is why more and more often focus is being placed on ensuring that this process is active and oriented at shaping the future. The basic characteristics of this management style is comprehensive problem solving and treating local government units as part of the surroundings. This means that from the perspective of the development of such units it is equally important to achieve socio-economic, environmental-spatial and financial effects, as well as to ensure that they are future-oriented (Niedziółka, 2010).

\section{Lubawa Municipality as an example of collaboration with local business - case study}

The town of Lubawa is situated in south-western part of Warmia-Masuria Province in Garb Lubawski mesoregion, which constitutes part of Chełmno-Dobrzyń Lakeland, in the south-eastern part of Iława County. The town is located at around $130 \mathrm{~m}$ above sea level. Three rivers cross the municipal area: the Elszka, the Sandela and the Jesionka. The centre of the town is a rectangular market square with adjacent streets, surrounded by a medieval defensive wall. Seven roads lead to Lubawa, which create convenient transport links to the regional and national transport network. The main element of the road network is national road No. 15 Olsztyn-Torun, which runs outside the basic municipal area as a bypass. Locations of Iława country and the town of Lubawa are presented in Figures 1 and 2.

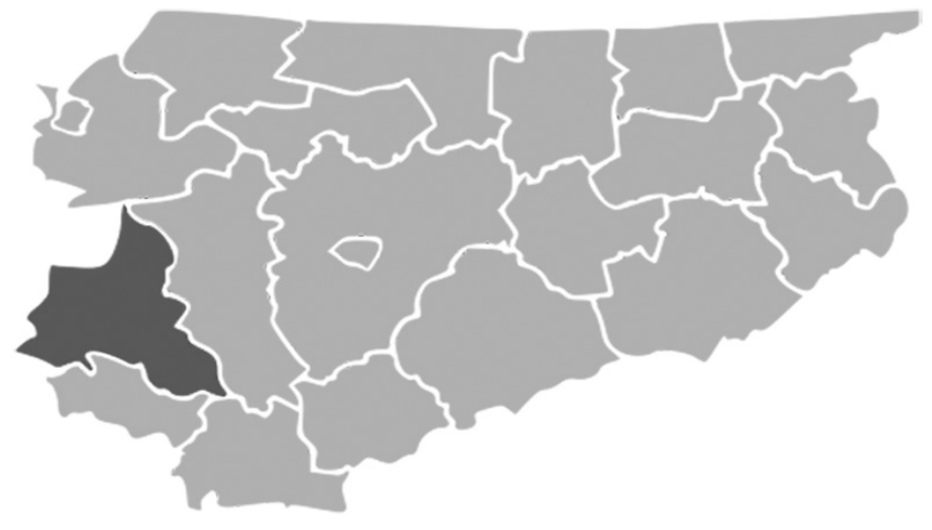

IMPORTANCE OF

A DIALOGUE BETWEEN

Tomasz Ankiewicz Zofia Wyszkowska Tomasz Michalski
Figure 1. Location of Iława County in WarmiaMasuria Province Source: Internet resources. 
IMPORTANCE OF

A DIALOGUE

BETWEEN

Tomasz Ankiewicz

Zofia Wyszkowska

Tomasz Michalski

Figure 2.

Location of the

Town of Lubawa in

Iława County

Source: Internet resources.

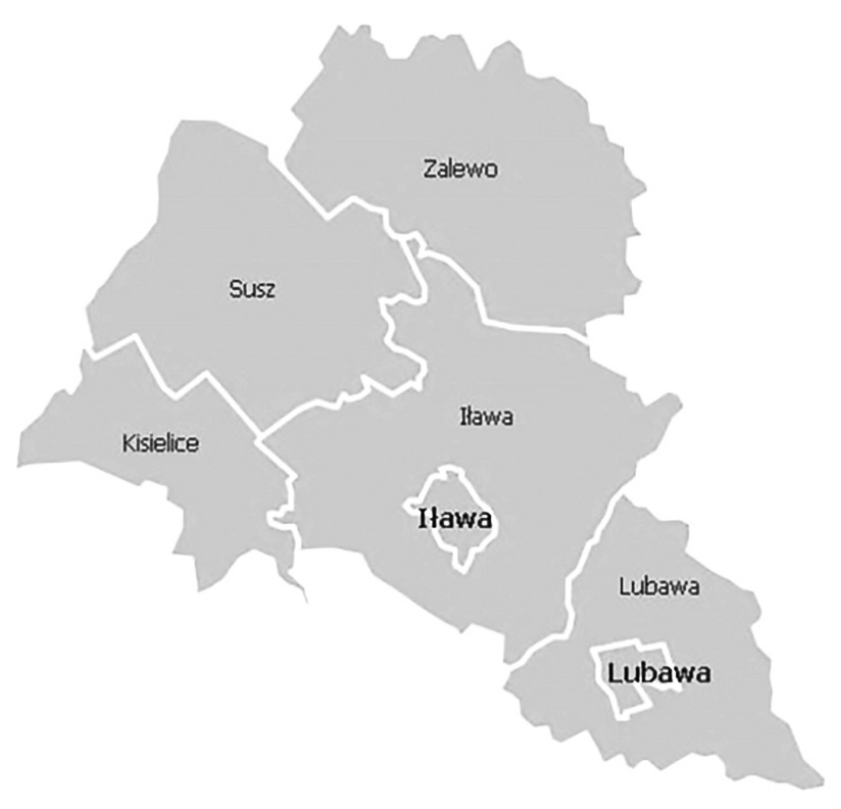

The town stretches over the area of $16.84 \mathrm{~km}^{2}$. Developed land takes up 20\% of the town area. A significant part of the area is agricultural land, taking up the total of $21 \%$ - $1633 \mathrm{ha}$. The share of forests is marginal, at ca $0.4 \%$ of the area. The town has 10,175 residents, including 9,838 registered for permanent residence (as of 31.12.2017).

Spatial management in Lubawa is based on the Local Spatial Development Plan adopted in 1998 with subsequent amendments. The Plan was adopted for the entire area of the Town of Lubawa. To date, thirteen partial changes to the Plan have been adopted, including three changes in the industrial district. The layout of the town in concentric. Industrial areas are located in the southern, northern and north-eastern part of the town, as well as partially in the north-western part. The northern part of the town has a direct link to national road No. 15 between Olsztyn-Torun. The southern part is situated adjacent to the Lubawa-Zajączkowo railway line, connected to the Warsaw-Gdańsk main line. The Town of Lubawa has potential new investment areas at its disposal. The General Directorate for National Roads and Motorways (GDDKiA) plans to build a bypass around Lubawa, connected to national road No. 15, which will decrease traffic in the centre of the town, reduce noise and excessive vibration, thus contributing positively to the quality of life of the local residents. On 25 March 2015, the latest resolution No. VI/47/2015 of the Lubawa Town Council was adopted concerning the local spatial development plan for the industrial district of the Town of Lubawa. The adoption 
of another resolution by the Lubawa Town Council regarding preparation of a local spatial development plan for the industrial district of the Town of Lubawa resulted from the need to update the intended purpose of those areas and to determine the way of their development on the basis of conclusions from the Study of the conditions and directions of spatial development in the Town of Lubawa. It should be taken into consideration that successful production, warehousing and service companies operate in the abovementioned area, whose activity has a positive impact on the local and supralocal labour market and regional development. Therefore, a need arose to ensure consistency of the local development plan with the Town Development Study in order to implement the town's policy set out in the current study. The current status of the industrial district after adoption of the plan in 2015 indicated 145.8784 ha of land intended for production, service and warehousing facilities. As compared to the original resolution of 26 May 1998, the size of the industrial district increased four times over the years until the adoption of the plan of 25 March 2015.

Even though the greatest advantage of the region of Warmia and Masuria is its natural features attracting tourists, in Lubawa itself and its closest surroundings there are no distinctive natural landscapes. Therefore, it was difficult for the town to implement plans of establishing new workplaces by promoting tourism. By analysing the number of staff employed by the largest employers in Lubawa it is clear to see that the main branch of economy in the town is industrial processing furniture production. Economic entities linked to construction are also developing. Table 1 shows the structure of business with three most important sectors in the region.

\begin{tabular}{lcc}
\hline \multicolumn{2}{c}{ NATIONAL ECONOMIC ENTITIES IN THE REGON REGISTER IN 2016 } \\
\hline & Ilawa County & $\begin{array}{l}\text { Lubawa } \\
\text { Municipality }\end{array}$ \\
\hline Total (no.) & $\mathbf{7 0 5 0}$ & $\mathbf{8 7 3}$ \\
\hline of which in: agricultural sector & 366 & 21 \\
\hline industrial sector & 788 & 104 \\
\hline construction sector & 881 & 93 \\
\hline per 10 thousand residents & 760 & 636 \\
\hline $\begin{array}{l}\text { Natural persons conducting business activity } \\
\text { per 10 thousand residents }\end{array}$ & 576 & \\
\hline
\end{tabular}

By analysing the number of people registered as unemployed it can be concluded that in the area of the Municipality of Lubawa the number of unemployed individuals keeps dropping. Most of all, the difference between the rates of unemployment registered in the province, in the council and in Lubawa alone should be stressed. This is mainly linked to the investments that the town
IMPORTANCE OF A DIALOGUE BETWEEN

Tomasz Ankiewicz Zofia Wyszkowska Tomasz Michalski

Table 1. National economic entities in the REGON register in 2016 Source: GUS (Central Statistical Office) data, Statystyczne Vademecum Samorzadowca 2017.

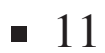




\begin{tabular}{|c|c|c|c|c|c|c|c|c|c|c|c|c|}
\hline Unit & & 2007 & 2008 & 2009 & 2010 & 2011 & 2012 & 2013 & 2014 & 2015 & 2016 & 2017 \\
\hline \multirow{3}{*}{$\begin{array}{l}\text { Town of } \\
\text { Lubawa }\end{array}$} & $\begin{array}{l}\text { number of } \\
\text { unemployed } \\
\text { persons }\end{array}$ & 434 & 312 & 410 & 412 & 400 & 457 & 365 & 233 & 222 & 191 & 128 \\
\hline & of which women & 266 & 187 & 240 & 231 & 256 & 259 & 235 & 149 & 144 & 112 & 80 \\
\hline & $\begin{array}{l}\text { rate of } \\
\text { registered } \\
\text { unemployment }\end{array}$ & $7.2 \%$ & $5.1 \%$ & $6.6 \%$ & $6.6 \%$ & $6.2 \%$ & $7.1 \%$ & $5.7 \%$ & $3.7 \%$ & $3.5 \%$ & $3.0 \%$ & $\begin{array}{l}\text { no } \\
\text { data }\end{array}$ \\
\hline \multirow{2}{*}{$\begin{array}{l}\text { Ilawa } \\
\text { County }\end{array}$} & $\begin{array}{l}\text { number of } \\
\text { unemployed } \\
\text { persons }\end{array}$ & 4445 & 3503 & 3983 & 3940 & 4472 & 4638 & 4272 & 3062 & 2492 & 2042 & 1670 \\
\hline & of which women & 2769 & 2141 & 2186 & 2165 & 2666 & 2657 & 2558 & 1899 & 1556 & 1257 & 1061 \\
\hline \multirow{3}{*}{$\begin{array}{l}\text { Warmia- } \\
\text {-Masuria } \\
\text { Province }\end{array}$} & $\begin{array}{l}\text { number of } \\
\text { unemployed } \\
\text { persons }\end{array}$ & 998995 & 87420 & 109181 & 105942 & 107333 & 113223 & 115873 & 98139 & 83510 & 73079 & 60003 \\
\hline & of which women & 58395 & 49707 & 56334 & 56128 & 58437 & 58970 & 59915 & 50985 & 44083 & 39627 & 33817 \\
\hline & $\begin{array}{l}\text { rate of } \\
\text { registered } \\
\text { unemployment }\end{array}$ & $10.7 \%$ & $9.4 \%$ & $11.7 \%$ & $11.1 \%$ & $11.3 \%$ & $12.0 \%$ & $12.4 \%$ & $10.6 \%$ & $9.1 \%$ & $8.1 \%$ & $\begin{array}{l}\text { no } \\
\text { data }\end{array}$ \\
\hline
\end{tabular}

Table 2.

Unemployment rate in Lubawa vs. the county and the province

Source: County Employment Office in Iława, Lubawa branch. has managed to secure over the last 20 years. Thanks to the "investor-friendly" atmosphere, local entrepreneurs can develop and raise the employment rate.

Table 3 shows the largest employers in the town with the number of staff employed between 2006-2017.

SWOT analysis included in the Socio-Economic Development Strategy for Lubawa Till 2025 indicates such strengths as: a dynamically developing economic sector - furniture production, presence of large recognisable foreign and national brands; developed network infrastructure - highly developed water and sewage system, good energy infrastructure, access to a gas network, currently the modernised waste treatment plant operates at 32\% capacity, which creates opportunities for continuous development of the town; investments financed by the town - the authorities allocate a high portion of expenses to infrastructural investments, which contribute directly to the town's economic and social development. Among the weaknesses were: a lack of technical infrastructure in investment areas, the town has potential new investment areas at its disposal but without the necessary infrastructure; insufficient collaboration between the local authorities and new companies, it is necessary to initiate ongoing collaboration based on an exchange of opinions and experiences, and on finding solutions to problems faced by both sides; poor promotion of entrepreneurship, no continuous supply of information and no advice centre for individuals interested in starting 


\begin{tabular}{lllll}
\hline Company name & Sector & $\begin{array}{l}\text { Employment } \\
\text { rate 2006 }\end{array}$ & $\begin{array}{l}\text { Employment } \\
\text { rate 2013 }\end{array}$ & $\begin{array}{l}\text { Employment } \\
\text { rate 2017 }\end{array}$ \\
\hline IKEA Industry Poland Sp. z o.o. & furniture & 1210 & 1633 & ca 1600 \\
\hline Szynaka-Meble Sp. Z o.o. & furniture & 253 & 776 & 1041 \\
\hline Lubawa S.A. & production-clothing & 251 & 155 & no data \\
\hline Intek Sp. z o.o. & construction & 245 & 284 & 260 \\
\hline Libro & furniture & 238 & 293 & 380 \\
\hline $\begin{array}{l}\text { Spółdzielnia Mleczarska Mlekovita } \\
\text { Lubawa Branch }\end{array}$ & food and dairy & 201 & 137 & 235 \\
\hline F.H.U. Szkłomal & glass-making & 89 & 116 & 124 \\
\hline Przetwórnia Owoców i Warzyw & food & 42 & 62 & 90 \\
\hline
\end{tabular}

Table 3.

business activity or changing or expanding the area of their activity. Among the opportunities listed were: inflow of external capital contributing to the development of a clean and modern service sector. External capital has played an important role in the development of Lubawa. With that capital new workplaces have been established, the residents' income has grown, which in turn has activated the local property market. Local business has also developed through cooperation and outsourcing. The list of threats included: significant domination of the furniture sector in the town's economy, which in case of a global market downturn may lead to a dramatic drop in the number of jobs in Lubawa.

In 2012 Lubawa became member of the International Network of Cities of the Good Life - Cittaslow. The idea behind Cittaslow originates from the Slow Food movement and was born in Italy in 1998. The first Polish cities joined the network in 2006. Subsequently, less than 2 years later, the Polish National Cittaslow Network of Cities was established. The cities included in the network adopt joint targets to improve the quality of life of their residents and to familiarise them with the good life culture. Most of all, they focus on pro-social and environmental activities. The idea behind Cittaslow also assumes the use of the latest technologies and innovative methods of city organisation to ensure there is no conflict between a peaceful pace of life and ongoing, calculated development. The international association is open to cities with less than 50 thousand residents which agree to implement its targets, i.e. to work comprehensively on improving the quality of life of their residents. Globally, nearly 240 cities from 30 countries have joined the network. The local authorities believe that the membership in the association does not only bring benefits related to the promotion of the town, but they also see it as a platform for the exchange of experiences and solutions for problems typical for small cities. Cittaslow is a coherent strategy of creating a specific image of the city (city branding), which should act as an impulse stimulating the economy and activating the residents, while the chosen path to implementation of its ideas can be a good starting point for small cities to mark their place, to increase their

Biggest employers as of 2017

Source: Own compilation based on the Socio-Economic

Development Strategy for Lubawa Till 2025 and data obtained from HR departments of the abovementioned companies. 
IMPORTANCE OF A DIALOGUE BETWEEN

Tomasz Ankiewicz Zofia Wyszkowska Tomasz Michalski attractiveness and thus to improve their competitiveness and economic position (Grzelak-Kostulska and Hołowiecka, 2011). In 2016, the Cittaslow Festival was organised in Lubawa, during which, among others, local craftsmen and entrepreneurs were able to show off their products. The defined vision of Lubawa presented in the Local Revitalisation Programme of the Municipality of Lubawa as part of the Supralocal Revitalisation Programme for cities from the Cittaslow network describes the town as socially and economically active as a result of actions taken to reduce social exclusion combined with an increased social activity and development of local entrepreneurship, among others, thanks to the rise in the number of qualified personnel.

Currently the Town of Lubawa holds the $6^{\text {th }}$ place in the Polish National Sustainable Development Ranking of Local Government Units in the urban municipality category. The Town of Lubawa was outscored by following municipalities: Karpacz, Krynica Morska, Sucha Beskidzka, Złotów. It should be noted that since 2011 Lubawa has held its position in the very top of the ranking virtually the entire time.

The characteristic feature of the Town of Lubawa as a territorial unit is high activity of the local authorities. In the examined period the municipality, together with local businesses, implemented several investment projects which contributed significantly to improving the quality of life of the local community. Several examples of good practices of cooperation between the local government and business, which played an important role in the socio-economic development of the Town of Lubawa, are presented below:

- 2014 - opening of a newly built road - extending Unii Europejskiej Street to Borek Street. The investment project was completed thanks to a good collaboration between the Municipality of Lubawa and Swedwood Poland, Lubawa Branch (now IKEA INDUSTRY). As part of the project, an asphalt road of around 600 running meters was built with the necessary technical infrastructure (street lighting, rain water drainage system, sewage and water system) and a pedestrian-bicycle lane on one side. The financial resources used for the construction of the road came from the sale of council property and a financial donation from Swedwood,

- 2017 - on the $25^{\text {th }}$ of August, during an official, extraordinary session of the Lubawa Town Council, entrepreneurs whose work had contributed to the town's development by increasing the employment figures, supporting sports clubs, events and investment projects organised by the local authorities were awarded a honorary title for their "Distinguished Service for the Town of Lubawa",

- 2017 - on September 27th, the Recreation Park was opened, whose construction was supported by the Danish Isabella Foundation with PLN 400 thousand,

- 2017 - on November13 ${ }^{\text {th }}$, the Mayor of Lubawa signed a donation agreement with representatives of Ikea Industry for the amount of PLN 700 thousand intended 
for modernisation of Borek Street. The project, whose total value amounts to PLN 1 million 700 thousand, will commence in 2018 and will involve construction of a pavement and a bicycle lane with street lighting, stretching from the roundabout to the IKEA facility, as well as construction of a new culvert on the River Elszka. The investment project will improve safety of road users in the industrial district.

Another sign of cooperation between the local government and business was the participation of ten women representing the local government, business and the banking sector in a photoshoot supporting preventative healthcare activities as part of the "Lubawa Fights Cancer" campaign. The participants of the photoshoot decided to promote healthy practices among Lubawa residents and encourage them to undergo preventative health checks. The entire project was initiated by the Lubawa Town Council.

In order to meet the needs of existing and future economic entities, local authorities adopted a resolution on 24 June 2015 regarding property tax exemption as part of the regional investment support programme. According to the resolution, tax exemption applies to newly built properties or their parts located in the town of Lubawa, connected to business activity carried out by entrepreneurs implementing initial investment projects and establishing new workplaces. The resolution will remain in force until 31 December 2020.

\section{Conclusions}

The analysis of the role of a dialogue between local government and local business has facilitated the following conclusions:

1. The involvement of municipal authorities in developmental processes is vital. Local authorities should initiate the entire process of increasing the attractiveness of the area and create conditions favourable to the development of local entrepreneurship.

2. Access to information is also vital for the development of local entrepreneurship. Access should be fast and easy, adjusted to the needs of existing entrepreneurs wishing to change or expand their activity, as well as to the needs of newly-established companies.

3. Attracting external investors, including foreign investors, depends to a large extent on the involvement of local authorities in the promotion of the region and on preparing an attractive offer for business negotiations. Other important factors include, for example, temporary exemption from tax or preparing an attractive land for investors.

4. When it comes to planning regional development, it is important to identify any economic, social, technical and technological barriers and to remove them.

5. Ongoing collaboration between local authorities and local entrepreneurs results in an improved quality of life of the local community, among others, by decreasing the unemployment rate and by implementing joint investments for the 
IMPORTANCE OF A DIALOGUE BETWEEN

Tomasz Ankiewicz Zofia Wyszkowska Tomasz Michalski common good, such as the construction of public utility buildings and safety improvements.

\section{References}

Avraham, E. (2004), Media strategies for improving an unfavourable city image, "Cities", Vol. 21 No. 6, pp. 471-479.

Baron, M. (2005), „Modelowe współpartnerstwo wielosektorowe”, in: Plawgo, B., Zaremba, W. (Eds.), Partnerskie Współdziałanie w sektorze publicznym i prywatnym, Fundacja Współczesne Zarządzanie, Białystok.

Cieślik, J., Koładkiewicz, I. (2014), Wspieranie rozwoju przedsiębiorczości w aglomeracjach miejskich. Narzędzia i instrumenty wspótpracy jednostek samorzqdu terytorialnego ze społecznościa przedsiębiorców na poziomie lokalnym, Społeczne Forum przedsiębiorczości, Warszawa.

Cilak, M. (2013), Instrumenty wspierania rozwoju gospodarczego stosowane przez samorzad terytorialny, Problematyka prawno finansowa, TNOiK Dom Organizatora, Toruń.

Dziemianowicz, W. (2008), Konkurencyjność gmin w kontekście relacji władze lokalne - inwestorzy zagraniczni, Wydawnictwo Uniwersytetu Warszawskiego, Warszawa.

Filipiak, B., Ruszała, J. (2009), Instytucje otoczenia biznesu, Rozwój, wsparcie, instrumenty, Wydawnictwo Difin, Warszawa.

Grzelak-Kostulska, E., Hołowiecka, B. (2011), „Kreowanie wizerunku miasta a rozwój funkcji turystycznej na przykładzie wybranych miast Polskiej Sieci Cittaslow”, in: Rapacz, A. (Ed.), Gospodarka turystyczna w regionie. Przedsiębiorstwo. Samorzqd. Wspótpraca, Uniwersytet Ekonomiczny we Wrocławiu, Wrocław.

Janik, W. (2004), Przedsiębiorczość i przedsiębiorstwo, WSPA, Lublin.

Kamiński, R. (2003), Stymulowanie rozwoju gospodarczego, Agencja Wydawniczo-Reklamowa MT, Warszawa.

Karaszewski, W. (2004), Bezpośrednie inwestycje zagraniczne. Polska na tle świata, Wydawnictwo TNOiK Dom Organizatora, Torun.

Klisiński, M., Szwaja, M. (2013), „Funkcje narzędzi marketingowych w kreowaniu wizerunku i marki gmin”, Zeszyty naukowe Uniwersytetu Szczecińskiego, No. 786, p. $93-100$.

Kłodziński, M. (2006), Aktywizacja społeczno-gospodarcza gmin wiejskich i małych miast, Instytut Rozwoju Wsi i Rolnictwa Polskiej Akademii Nauk, Warszawa.

Kuciński, K. (2010), „Regionalna perspektywa przedsiębiorczości”, in: Kuciński, K. (Ed.), Przedsiębiorczość a rozwój regionalny w Polsce, Difin, Warszawa.

Lundberg, H., Anderesen, E. (2012), "Cooperation among companies, universities and local governmentv in a Swedish context", Industrial Marketing Management, Vol. 41 No. 3, pp. 429-437.

Mazur, D. (2015), ,Współpraca sektora nauki, biznesu i administracji publicznej jako główne wyzwanie współczesnej polityki rozwoju miasta na przykładzie Krakowa", Zarzadzanie Publiczne, Vol. 1 No. 29, pp. 1-10.

Osiński, J. (2008), „Administracja publiczna a gospodarka regionalna i lokalna”, in: 
Strzelecki, Z. (Ed.), Gospodarka regionalna i lokalna, Wydawnictwo Naukowe PWN, Warszawa.

Pakulska, T. (2010), „Bezpośrednie inwestycje zagraniczne w rozwoju przedsiębiorczości w regionie", in: Kuciński, K. (Ed.), Przedsiębiorczość a rozwój regionalny, Wydawnictwo Difin, Warszawa.

Piasecki, A.K. (2009), Samorzad terytorialny i wspólnoty lokalne, Wydawnictwo Naukowe PWN, Warszawa.

Niedziółka, M. (2010), „Przedsiębiorczość gminy a rozwój regionalny”, in: Kuciński, K. (Ed.), Przedsiębiorczość a rozwój regionalny, Wydawnictwo Difin, Warszawa.

Snellen, I. (2002), "Eletronic governance: implications for citizens, politiciana and public servants", International Review of Administrational Science, Vol. 68 No. 2. DOI: $10.1177 / 0020852302682002$

Woodside, A.G., Lysonski, S. (1989), "A General Model of Traveler Destination Choice”, Journal of Travel Research, Vol. 27 No. 4, pp. 8-14.

Zakrzewska-Półtorak, A. (2010), „Współczesne uwarunkowania rozwoju gospodarki regionalnej i lokalnej w Polsce”, in: Brol, R. (Ed.), Gospodarka lokalna w teorii i praktyce, Prace Naukowe Uniwersytetu Ekonomicznego we Wrocławiu, No. 109, Wrocław.

Strategia Rozwoju Społeczno-Gospodarczego Lubawy do 2025, Gmina Miejska Lubawa, Lubawa 2008.

Lokalny Program rewitalizacji gminy Miejskiej Lubawa w ramach Ponadlokalnego programu rewitalizacji sieci miast Cittaslow, Warmińsko-Mazurska Agencja Rozwoju Regionalnego S.A. w Olsztynie, 2017.
IMPORTANCE OF

A DIALOGUE BETWEEN

Tomasz Ankiewicz Zofia Wyszkowska

Tomasz Michalski 